\title{
A karriersikeresség vizsgálata a gazdálkodási területen frissen végzettek körében
}

A felsőoktatás és a munkaerőpiac illeszkedése fontos követelmény a felsőoktatási intézményekkel szemben. Ennek mérésére számos megközelítés létezik, jelen tanulmány a frissdiplomások objektív és szubjektív karriersikerességének befolyásoló tényezőit helyezi középpontba. Az empirikus kutatás a 2011 és 2014 közötti Frissdiplomás-adatbázis alapján 4515, gazdaságtudományi területen frissen végzett hallgató válaszainak elemzésére épül. A karriersikerességet a Diplomás Pályakövető Rendszer változói alapján mind objektív, mind szubjektív dimenziókat magában foglaló koncepcionális modellel, OLS-regresszió segítségével mértük. Az eredmények azt mutatják, hogy a végzettek szubjektív szempontból sikeresebbek, mint objektív szempontból, ami azt jelzi, hogy nem elegendő az objektív tényezőket vizsgálni, hanem a szubjektív dimenziót is elemezni kell. Ez alapján - illetve az egyéb befolyásoló tényezők figyelembevételével - a felsőoktatási intézményeknek nagyobb hangsúlyt kell fektetniük a szubjektív sikerességet nagyobb mértékben meghatározó „puha készségek” fejlesztésére.

Journal of Economic Literature (JEL) kód: I23, J24, 015.

A felsőoktatási intézmények egyik értékteremtő feladata, hogy a hallgatók olyan oktatásban, képzésben részesüljenek, amelyet a munkaerőpiac szereplői is elismernek (Lane-Johnstone [2012]). Ez az elismerés pedig nagyrészt azt jelenti, hogy a munkáltatók az egyetemekről kilépő diákokat megfelelőnek tartják arra, hogy náluk munkába álljanak. Idekapcsolódóan felmerülhet a kérdés, hogy mi a fontosabb az intézmény számára: az, hogy fel tudja mutatni, végzettjei képesek gyorsan munkát találni, ami egyfajta rövid távú sikernek könyvelhető el, vagy az, ha

* A jelen dokumentum az Oktatási Hivatal DPR - Frissdiplomások 2011-2014 adatbázisának felhasználásával készült. A tanulmány a TKP2020-IKA-08 számú projekt a Nemzeti Kutatási, Fejlesztési és Innovációs Alapból biztosított támogatással, a Tématerületi Kiválósági Program 2020 (2020-4.1.1TKP2020) pályázati program finanszírozásában valósult meg.

Szabó-Bálint Brigitta a Pécsi Tudományegyetem Közgazdaságtudományi Kar Vezetés- és Szervezéstudományi Intézet tanársegédje (e-mail: balintb@ktk.pte.hu).

Sipos Norbert a Pécsi Tudományegyetem Közgazdaságtudományi Kar Vezetés- és Szervezéstudományi Intézet adjunktusa (e-mail: sipos.norbert@ktk.pte.hu).

A kézirat első változata 2020. július 27-én érkezett szerkesztőségünkbe.

DOI: http://dx.doi.org/10.18414/KSZ.2021.5.515 
hangsúlyt fektet arra is, hogy a pályakezdő hallgatók a képzettségüknek minél inkább megfelelő, minőségi munkakört tudjanak betölteni, valamint kellően felkészültek legyenek arra, hogy sikeresen kiépítsék életpályájukat. Egy egyetem érdemét nagymértékben szolgálja, ha bebizonyosodik, hogy végzett hallgatói sikeres karriert építettek ki. A sikeres dolgozók pedig közvetve egy nemzet gazdaságának növekedéséhez járulnak hozzá (Carnevale-Rose [2012]). Ezért az egyetemeknek érdemes mérni végzettjeik karriersikerét is.

A frissdiplomások munkaerőpiaci sikerességét Magyarországon jellemzően a hagyományos közgazdaságtani mutatókkal mérik, amelyek leginkább a jövedelmet, illetve a foglalkoztatottá válás esélyét vizsgálják, pedig a siker értelmezése ennél összetettebb (Veroszta [2011]). A Diplomás Pályakövető Rendszer (DPR) felmérései és eredményei az intézmények számára hasznos visszajelzést szolgáltathatnak többek között arról, hogy végzett diákjaik milyen könnyen és gyorsan találtak munkát, valamint képesek-e kamatoztatni az oktatás során megszerzett ismereteiket (Veroszta [2015c]).

Tanulmányunkban az eredmények kombinált elemzésével először is arra kívánunk választ találni, hogy a frissen végzettek (1-5 éves időtartamon belül) menynyire tekinthetők objektív és szubjektív szempontból sikeresnek. Ehhez egy általunk megalkotott mérési modellt használunk fel, amely nagyban épít a szakirodalomban fellelhető mérési módszerekre, de azokat újszerủen, a DPR-rendszerhez igazodva kombináljuk. Ezt követően OLS-regresszióval vizsgáljuk meg a karriersikerességet befolyásoló tényezőket.

A DPR-adatbázis lehetőséget ad a különböző képzési területeken abszolvált hallgatók elemzésére is, tanulmányunkban a gazdaságtudományi területen végzetteket vizsgáljuk. Választásunkat az indokolja, hogy Varga [2013] szerint mind nemzetközi, mind hazai felméréseket nézve - a müszaki tudományok végzettjei mellett - jellemzően ők teljesítenek a legjobban a munkaerőpiacon.

Elsőként a különböző sikerértelmezéseket és mérési lehetőségeket, valamint a siker elérését befolyásoló tényezőket ismertetjük. A DPR-keretrendszer és modellünk változóinak bemutatását követő módszertani rész bővebb áttekintést ad mérési modellünkröl. Az eredményeinkből levont következtetéseink zárják a tanulmányt.

\section{A karriersiker szakirodalmi áttekintése}

Arthur és szerzőtársai [2005] a sikert az egyén munkatapasztalatainak eredményeként kezeli: a karriersiker a munkával kapcsolatos kívánatos kimenet egy személy munkatapasztalatainak bármely időpontjában. Judge-Kammeyer-Mueller [2007] úgy tekint a sikerre, mint valós vagy észlelt eredményekre, amelyeket az egyén munkatapasztalatai során felhalmoz. Ng és szerzőtársai [2005] szerint az életpálya sikerességét objektív és szubjektív tényezők jellemzik, ezért a sikert lehet objektív és szubjektív mutatókkal mérni. Előzőre példa a fizetés, az előléptetés, a pozíció (Gattiker-Larwood [1989], Jaskolka és szerzötársai [1985]), a magasabb jövedelem és a növekvő elismerés. A szubjektív mérés pedig az egyén érzéseiben jelenik 
meg, például örömként vagy bánatként (Koncz [2013]). A karrier sikerességének mérése azért is fontos, mert az átélt siker hozzájárul a jövőbeli karriercélok eléréséhez (Spurk és szerzőtársai [2019]), továbbá növelheti a foglalkoztatási esélyeket (Hobfoll és szerzötársai [2018], Blokker és szerzötársai [2019]), ugyanis bizonyított, hogy a sikeres emberek karrierlehetőségei nagyobbak, mint kevésbé sikeres társaiké (például Singh és szerzőtársai [2009]).

\section{Az objektív és a szubjektív karriersiker értelmezése}

Hagyományosan a sikeres karriert kizárólag a társadalom által értékelt jutalmak elérésének tulajdonították (Baruch-Bozionelos [2010]). Ilyen jutalmak például - ahogy Heslin [2005a] is leírja - egy szervezetbeli vagy egy szakmabeli státus, presztízs megszerzése, a ranglétrán való elörehaladás üteme vagy a pénzügyi teljesítmény. Ez általában a siker objektív vagy külső megközelítésére utal, amely egy külső megfigyelő szemléletén keresztül ítéli meg a sikert, vagy objektív mércéket használ fel annak megmérésére (Baruch-Bozionelos [2010]). Arthur és szerzötársai [2005] szerint is az objektív felfogás egy külső szempontra utal, amely többnyire tényszerü mutatókkal értékeli egy egyén karrierhelyzetét. Ez alapján megfelelő indikátor a fizetés vagy a fizetés növekedésének mértéke. Gunz-Mayrhofer [2011] megemlíti még az anyagi sikert (a gazdagságot, a tulajdont stb.), a társadalmi hírnevet, a presztízst, a befolyást, a tudást, a kapcsolatokat és az egészséget.

Heslin [2005a], [2005b] kiemeli, hogy a siker objektív méröi különbözhetnek karriertípusonként, szakmánként. Más mércét alkalmaz egy tanár (diákjainak tanulmányi eredményei), mint egy buszsoför (baleset nélkül megtett kilométerek száma). Ezek az objektív indikátorok nem feltétlenül csak a fizetéshez vagy az előmenetelhez kötődhetnek, és nem feltétlenül szükséges, hogy mások elismerjék ezeket az eredményeket. Ettöl függetlenül is lehet sikerességet érezni.

A szubjektív karriersiker Van Maanen [1977] alapján az egyén saját felfogása és értékelése saját karrierjéröl a számára fontos szempontok szerint. A szubjektív karriersiker Heslin [2005b] szerint attól függ, hogy az egyén mennyire elégedett a munkájával, illetve Kraimer és szerzőtársai [2019] szerint attól, hogy az adott személy mennyire elégedett saját karrierjével. A kutatók ezt többnyire a fizetéssel, az elömenetellel és a képességek fejlesztésével való elégedettség arányával mérik. Később a lista kiegészült a munka-magánélet egyensúlyával és a hasznos, értéket teremtő cselekvéssel való elégedettséggel. Gunz-Mayrhofer [2011] hozzáveszi még az eredmények fölött érzett büszkeséget, az önértékelést, az elkötelezettséget, a kapcsolatokat és az erkölcsi elégedettséget.

A kétféle siker közötti kapcsolatot számos kutató vizsgálta abból a szempontból, hogy melyik megközelítés milyen hatással van a másikra. Arthur és szerzőtársai [2005] 68, a téma szempontjából releváns publikációt vizsgált meg. A szerzők az áttekintett cikkek 37 százalékában egyirányú kapcsolatot találtak: az objektív siker befolyásolja a szubjektívet, ebből következően az egyének a sikerüket az objektív teljesítményük alapján értelmezik. Ezzel szemben a megvizsgált publikációk 19 százaléka 
szerint a szubjektív siker határozza meg az objektívet, 32 százaléka szerint pedig a szubjektív és objektív karriersiker között kétirányú, kölcsönös a kapcsolat. A maradék 12 százalék szerint nincs összefüggés a kétféle értelmezés között.

Poole és szerzőtársai [1993] szerint az objektív siker hatással van a szubjektív sikerre. Seibert és szerzőtársai [2001] arra jutott, hogy a két szempont egymástól függ. Vannak olyan kutatók, akik a szubjektív siker szerepét hangsúlyozzák az objektívvel szemben. Például Sturges [1999] felhívja a figyelmet arra, hogy mind a két nézet fontos egy ember sikerérzetének megértéséhez, viszont bizonyított, hogy bizonyos emberek számára - például a nőknél - a szubjektív nézet meghatározóbb, mint az objektív. Sturges több mủvet idéz: 1. Russo és szerzőtársai [1991] a férfiak esetében kapcsolatot talált a fizetés, valamint a rang és a siker között, míg a nőknél nem. 2. Nicholson-West [1988] szerint a nök hajlamosabbak karriersikerüket egyenlővé tenni például a személyes fejlődésükkel, valamint 3. Asplund [1988] szerint az érdekes és a kihívást jelentő munkával, 4. Powell-Mainiero [1992] szerint a munkamagánélet közötti egyensúly megteremtésével. Sturges [1999] szerint a női menedzsereket sikerük meghatározásában befolyásolja egyrészt a szocializációjuk, másrészt a szervezeti korlátok (például az elörelépés nehézsége).

Abele és szerzőtársai [2011] vizsgálataiban továbbment, és vizsgálta, hogy a foglalkoztatási viszony jellege (önfoglalkoztató-e az egyén, vagy az állami, illetve a versenyszférában dolgozik) befolyásolja-e az objektív és a szubjektív karrier sikerének a kapcsolatát. A szerzők azt állapították meg, hogy az önfoglalkoztató személyek esetében erösebb a kétféle siker közötti kapcsolat, míg a leggyengébb az állami szférában dolgozók körében. Továbbá arra jutottak, hogy erősebb az objektív és a szubjektív siker közötti kapcsolat, ha a szubjektív sikert másokhoz viszonyítva méri az egyén, és gyengébb, ha saját maga számára fogalmaz meg elérendő standardokat. Következtetésként azt fogalmazták meg, hogy a szubjektív siker az emberek végső célja, viszont fontos az objektív eredmények eléréséhez. Ha valakinek kevés szubjektív sikert sikerül elérnie, akkor az csalódottsághoz, a motiváció hiányához vezethet. Ellenkező esetben erőt adhat az objektív sikercélok eléréséhez. A szerzők az említettek alapján mindkét sikertípust bevonták az elemzésükbe, mivel azok együttesen járulhatnak hozzá a sikerérzethez.

\section{A karriersiker értelmezését és elérését befolyásoló tényezők}

Fontos kérdés, hogy mi befolyásolja az egyének karrierértékelését. Előfordulhat, hogy két személy ugyanolyan eredményeket ért el életpályája során, amit az egyikük sikeresnek értékel, míg a másikuk nem. Dries és szerzötársai [2008] több befolyásoló tényezőt nevez meg a siker értelmezése kapcsán. Először is megemlíthető a történelmi és a kulturális háttér mint meghatározó szempont a siker fogalmának azonosítása során. Továbbá a szubkulturális és a gazdasági-társadalmi viszonyok is hatással vannak arra, ahogy az egyének a sikert értelmezik, a karrierjüket megélik. A Dries és szerzőtársai [2008] példákat említ különböző szerzőktől arra vonatkozóan, hogy a fizikai munkások másként értelmezik a karriert és a sikert is, mint a szellemiek. A fizikai 
munkakörben dolgozók például hajlamosak a szakmában eltöltött időt, a szakmai tapasztalatot és a munka során átélt veszélyek mennyiségét tekinteni a siker jellemzőinek. A szocializáció folyamata is releváns lehet a siker megfogalmazásában. A szocializáció hatását a nők gyakran másképpen értékelik, mint a férfiak.

A bemutatott hivatkozások szerint akár egy felsőoktatási intézmény is megfogalmazhatja saját maga és hallgatói számára, hogy kit milyen feltételek mellett tekint sikeresnek. Ha ezeket a sikerkritériumokat nemzeti szinten fogalmazzák meg, akkor az lehetőséget ad az egyes intézmények összehasonlítására is. Mi is egy ilyen modell kialakítására törekedtünk kutatásunk során egy olyan országosan használt felmérés (DPR) alapján, amelynek változói erre lehetőséget is biztosítanak.

A sikeres életpálya témakörén belül ugyancsak gyakran kutatott téma, hogy mi befolyásolja azt, hogy valaki sikeressé váljon, mi kell a sikerhez (GattikerLarwood [1989], Seibert és szerzőtársai [1999], Dries és szerzötársai [2008], Alzyoud [2017]). A szakirodalomban többféle csoportosítás is fellelhetö a befolyásoló tényezők kapcsán (lásd Callanan [2003] vagy Ng és szerzőtársai [2005]). Mi Szabó-Bálint-Karoliny [2019]-ből indulunk ki, a mely megemlíti az egyéni jellemzőket (demográfiai tényezők), a személyes tényezőket (emberitőke-elemek és személyes jellemvonások) és a szervezeti jellemzőket (mint például méret, társadalmi elismertség vagy működési iparág).

Az egyéni jellemzők kapcsán először Callanan [2003]-at érdemes említeni, amely leírja, hogy a demográfiai jellemzők közül például a kor pozitív kapcsolatban áll a sikerrel, föleg az objektíven megragadható sikerrel. Judge és szerzőtársai [1995] szerint feltételezhetően azért, mert a külső eredmények idővel felhalmozódnak. Még ma is sok országban vagy szervezetben helytálló azon megállapításuk, hogy a nőknek és a kisebbségi csoportokhoz tartozóknak rosszabbak az esélyeik a siker elérésére (gondolhatunk itt a ma is létezö üvegplafonhatásra).

A személyes tényezők, azon belül az emberitöke-jellemzők kapcsán Koncz [2013] úgy gondolja, hogy „az iskolázottság színvonala és a szakképzettség jellege döntően meghatározza a siker esélyét" (34. o.). Kiemeli, hogy minél magasabb valakinek az iskolai végzettsége, annál eredményesebb életpálya kiépítésére van lehetősége. Judge és szerzőtársai [1995] azt azonosította, hogy az iskolázottság szintje, minősége, presztízse és foka a pénzügyi sikerre vannak jó hatással, továbbá a munkaidő hossza és a munkatapasztalatok széles sora is általában pozitívan befolyásolja a sikert.

A személyes jellemzők kapcsán Seibert és szerzőtársai [1999] arra jutott, hogy a proaktív viselkedés pozitívan befolyásolja a kétféle sikertípust. Gerli és szerzőtársai [2015] szerint az érzelmi kompetenciák (például tudatosság, önszabályozás és rugalmasság) nincsenek közvetlen hatással az elörehaladásra (objektív sikerre), míg a szociális kompetenciák (például empátia, kapcsolatépítés, önbizalom, mások fejlesztése) és a siker között kimutatható a kapcsolat.

A szervezeti tulajdonságok kapcsán például Judge és szerzőtársai [1995] olyan szervezeti jellemzőket vizsgált, mint a szervezet mérete, sikeressége, társadalmi ismertsége vagy iparága, amelyek közül a méret és a sikeresség az előléptetéssel pozitív kapcsolatot mutatott. Kiemelendő, hogy a méret a fizetés mértékével (objektív siker) ellentétesen mozgott, míg bizonyos jellemzők a szubjektív siker elérését segítették. 
Az eredmények összességében az mutatják, hogy míg a demográfiai tényezők és az emberi tőke elemei, valamint bizonyos szervezeti jellemzők elsősorban az objektív karriersikerhez járulnak hozzá, addig a személyes jellemvonások inkább a szubjektív karriersiker realizálására lehetnek hatással.

\section{A Diplomás Pályakövető Rendszer}

A magyarországi pályakövetés bevezetését a Diplomás Pályakövető Rendszer kiépítése tette lehetővé, amely a frissdiplomásokhoz kapcsolódó legfontosabb jellemzőket (munkaerőpiaci elhelyezkedés, diplomaszerzés kitolódása, munka és képzés illeszkedése, külföldi orientáció stb.) önkitöltős, online kérdőív formájában gyüjti össze. A rendszer elindításában és működtetésében fontos szerepet töltött be az Educatio Társadalmi Szolgáltató Nonprofit Kft. (később az Oktatási Hivatal), ennek a szervezetnek köszönhetően beszélhetünk 2010-től kezdve a magyar pályakövetés müködéséröl. A DPR nem mentes a módszertani kritikától, elsősorban a válaszadás módját, a minta hiányosságait és a válaszmegtagadást szokták felróni a megbízhatóságával kapcsolatban folytatott beszélgetések során (Veroszta [2015c]).

Mindezek figyelembevételével, az említett hibák mellett a DPR egy nagy volumenü, szinte a teljes sokaságot lefedő felmérés, ebből adódóan az adatok bizonytalansága ellenére a benne megjelenő válaszokra elfogadható elemzések épülhetnek. Ezt az is megerősíti, hogy a hároméveként megvalósított szóbeli lekérdezések rendre megerősítették az azonosított tendenciákat, trendeket, másrészt az Adminisztratív Adatbázisok Egyesítésének (AAE) ${ }^{1}$ survey adataival vizsgálták megbízhatóságát. Az AAE az egyes adatregiszterekben tárolt objektív információk összekapcsolására épül, és ebből adódóan teljes körü, objektív, megbízhatósága kétségen felül áll (elfogadva az állam által gyüjtött adatok esetlegesen felmerülő tudatos torzítását a munkáltatók részéről) (Veroszta [2015a]). Sipos [2018] megállapította, hogy a bér, a foglalkoztatás, a munkahely megyéje szerint nem mutatható ki különbség a DPR és az AAE között, ebböl adódóan a DPR-re épülő elemzések is fontosak és értékesek a kutatók, valamint az oktatáspolitikai döntéshozók számára. ${ }^{2}$

\section{Az empirikus kutatás módszertana}

A vizsgálat alapjául a Diplomás Pályakövető Rendszer - megfelelő módszertani és szakmai szempontok figyelembevételével egységes szerkezetbe tett - Frissdiplomások 2011-2014 közötti adatbázisai szolgáltak. Az online kérdőív válaszadási

\footnotetext{
${ }^{1}$ https://www.diplomantul.hu/adminisztrativ-adatbazisok-egyesitese.

${ }^{2}$ A DPR törvényi hátteréről és változásairól lásd 2005. évi CXXXIX. törvény a felsőoktatásról; 2011. évi CCIV. törvény a nemzeti felsőoktatásról; 87/2015. (IV. 9.) kormányrendelet a nemzeti felsőoktatásról szóló 2011. évi CCIV. törvény egyes rendelkezéseinek végrehajtásáról; 2019. évi LXXX. törvény a szakképzésről.
} 
aránya átlagosan 15 százalékot meghaladó mértékü az egy, a három és az öt éve végzettek körében. Mivel a felmérés nem longitudinális, így egy diplomás többször is szerepelhet az adatbázisban (például valaki az alapszak elvégzése után egy és három évvel is válaszolt, illetve három évvel az alap- és egy évvel a folytatólagos mesterszak elvégzése után). Ez azt jelenti, hogy alapvetően itt személyekröl van szó, ugyanakkor egy-egy rekord egy-egy végzettségnek felel meg. A végzettséghez kapcsolódó személy munkaerőpiaci sikerességének vizsgálata ezen sajátosság figyelembevételével végezhető el. ${ }^{3}$

Összesen 90740 végzettség szerepel az adatbázisban. Mindegyik intézmény a végzett hallgatók legalább 90 százalékának elérését vállalta, így a kérdőívfelvétel teljes körünek tekinthető, továbbá a 31-33 intézmény jellemzően a magyar felsőoktatásban tanuló végzett hallgatók több mint 90 százalékát fedi le. Az egyes adatbázisok különböző kódolást alkalmaztak bizonyos változóknál, ezek egységesítése a szakmai tartalom homogenitásának megőrzésével valósult meg. Emellett azonban a vizsgálat céljainak érdekében az alábbi tényezők szerint szükült a vizsgálati elemszám:

- képzési terület: gazdaságtudományok,

- életkor: a válaszadás időpontjában 30 éves vagy fiatalabb,

- az összes vizsgált változó szerint teljes körü kitöltés.

A szükítés következtében az eredeti reprezentativitási szempontok (nem, munkarend, kar, végzés éve) alkalmazása nem indokolt, hiszen a fenti szürőtényezőket ezek nem foglalják magukban, és nem is plauzibilis ezek újbóli elöállítása. Mindezek figyelembevételével az 1. táblázat mutatja be az adatbázis főbb jellemzőit.

\section{1. táblázat}

A Frissdiplomás 2011-2014 alapsokaság és minta jellemzői

\begin{tabular}{lcccccc}
\hline & $\begin{array}{c}\text { Minta- } \\
\text { elemszám } \\
(\text { fó) }\end{array}$ & $\begin{array}{c}\text { Részt vevő } \\
\text { intézmények } \\
\text { alapsokasága } \\
\text { (fö) }\end{array}$ & $\begin{array}{c}\text { Az adatbázis } \\
\text { elemszáma } \\
(\text { fó) }\end{array}$ & $\begin{array}{c}\text { Átlagos } \\
\text { válaszadási } \\
\text { ráta } \\
\text { (százalék) }\end{array}$ & $\begin{array}{c}\text { Gazdaság- } \\
\text { tudományi } \\
\text { terület (fó) }\end{array}$ & $\begin{array}{c}\text { Az } \\
\text { intézmények } \\
\text { száma }\end{array}$ \\
\hline 2011 & 862 & 100785 & 20453 & 20,3 & 3855 & 31 \\
2012 & 1098 & 163964 & 24890 & 15,2 & 5190 & 32 \\
2013 & 1639 & 148548 & 24233 & 16,3 & 5082 & 32 \\
2014 & 916 & 176383 & 21164 & 12,0 & 4253 & 33 \\
Összesen & 4515 & 589680 & 90740 & 15,4 & 18380 & \\
\hline
\end{tabular}

Forrás: Kiss-Veroszta [2012], Veroszta [2013a], [2013b], [2015b] DPR - Frissdiplomások 20112014. évi adatai alapján

\footnotetext{
${ }^{3}$ Jelen tanulmányban foglalt számítások és az azokból levont következtetések kizárólag a szerzők szellemi terméke.
} 
Végzett egyetemi hallgatók munkaeröpiaci sikerességének eddigi vizsgálatai a DPR adatbázisán

A validáció szempontjából fontos, hogy az adatbázisokon már egyéb, hasonló területen végzett kutatás eredményeit is figyelembe kell venni, egyrészt a módszertan, másrészt a felhasznált változók mérlegelése céljából. Veroszta [2015c] objektív sikertényezőként a fizetés mértékét és a FEOR-alapú foglalkoztatási illeszkedést vette figyelembe, míg szubjektív tényezőként a munkával való elégedettséggel kapcsolatos elemeket. Elsősorban az elégedettek (1-4-es skálán a 3-as és a 4-es értéket jelölők) arányát vizsgálata. Végezetül a munkával kapcsolatos általános elégedettségi szintet bináris logisztikus regresszióval ötlépéses modellépítkezés segítségével elemezte. A szerző egy korábbi tanulmányában az objektív dimenziót oly módon vizsgálta, hogy létrehozott egy, a betöltött pozíciót a cégmérettel és a vezetői szinttel kombinált mutatót (Veroszta [2011]). Az indikátor két lehetséges kimenete a „kisvezetö” (100 főnél kisebb cég vezetője vagy 100 fönél nagyobb cégben alsó szintű vezető) és a „nagyvezetö” (felső- vagy középvezető 100 fönél nagyobb cégben) volt.

Kazár-Kürtösi [2017] szintén országos DPR-adatokat (2012-es felmérés) használt az oktatásba történő befektetés és így áttételesen a sikeresség kimutatására a nappali tagozaton, gazdaságtudományi képzési területen végzettek körében. A szerzőpáros az objektív sikerességhez az elhelyezkedési időt, a havi nettó jövedelmet, a pályán való elhelyezkedést, valamint a munkához a felsőfokú végzettség szükségességének mutatóit vonta be. Az első két tényező esetében kiszűrte a kiugró értékeket. Az objektív sikerességi tényezőkön futtatott klaszteranalízis segítségével kialakult hat csoport esetében megvizsgálta a demográfiai tényezőket, majd összevetette a munkához kapcsolódó szubjektív tényezők megítélésével, és ennek függvényében keresett eltéréseket, egyezöségeket.

Vinogradov [2017] a Szent István Egyetem végzettjei körében 2013-2016 között folytatott felmérések segítségével vizsgálta a munkaerőpiaci sikerességet, leíró statisztikák mellett a sikeresség függő változójára futtatott bináris logisztikus regreszsziót. Az objektív tényezőknél a fizetéseket, az elhelyezkedés idejét, a szakmai illeszkedést vette figyelembe (kiszürve a kiugró értékeket). Az elemzést kiegészítette olyan keresztváltozókkal, amelyek rangsorokat is magukban foglaltak, például hogy a fizetés a felső 25. percentilisbe tartozik-e, illetve hogy a saját szakterületnek megfelelö munkát végez-e a vizsgált személy. A szubjektív megítélésnél ugyancsak a munkával kapcsolatos megelégedéseket azonosította. Kontrollváltozóként egyéb demográfiai, tanulmányokhoz kötődő tényzőket is bevont az elemzésbe.

Kiss [2014], [2016] és Kiss-Barizsné Hadházi [2016] foglalkozott még a sikerességgel. Jellemzően leíró statisztikai eszközöket alkalmaztak, illetve a szakterületi kapcsolódás, valamint az elhelyezkedés ideje jelenik meg a változók között. 


\section{A frissdiplomások karriersikerességének koncepcionális modellje}

Mindezek figyelembevételével alakítottuk ki tanulmányunk módszertanát. Kiindulási pontként a rendelkezésre álló adatbázisok (DPR - Frissdiplomások, 2011-2014) szolgálnak, és a szakirodalmi áttekintés, valamint az adatok magyar tapasztalatainak függvényében azonosítottuk azokat az objektív és szubjektív tényezőket, amelyek figyelembe vehetők a siker meghatározásához. Az 1. ábra mutatja az általunk alkalmazott sikerességet mérő változókat.

\section{1. ábra}

A frissdiplomások karriersikerességének koncepcionális modellje

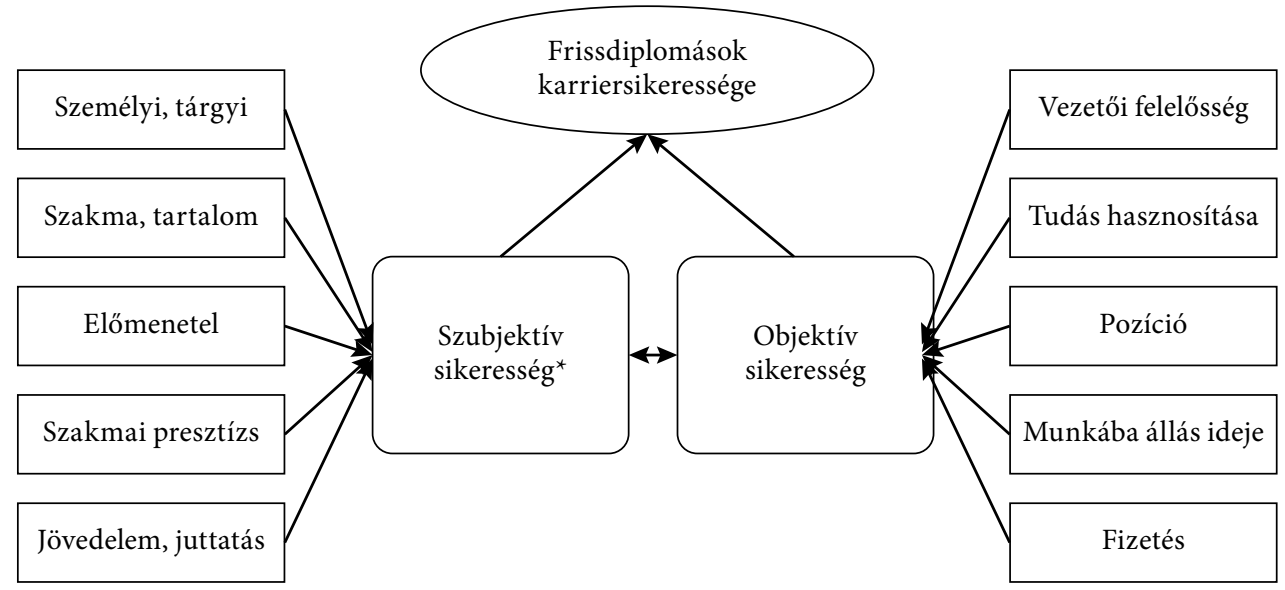

* A szubjektív sikeresség tényezőinél az elégedettség mértékét vettük figyelembe.

Forrás: saját szerkesztés.

Az indikátorok kialakításához alapul szolgált számos, fent ismertetett tanulmány. ${ }^{4}$ Ezekre építkezve határoztuk meg az objektív és a szubjektív sikeresség mutatóit.

Az objektív sikeresség indikátorai

ОВJ1 - VEZETŐI FELELŐssÉG: alkalmazottak/beosztottak száma és vállalati méret ami a szakmai státusra, a szervezeti hierarchiában elfoglalt helyre utal,

OBJ2 - TUDÁS HASZNOSíTÁSA: tanulmányok és a képzettség alkalmazása a munkában - a szakmai előmenetelt és a tudás mértékét mutathatja,

ОВJ3 - POzícIó: szintén a szakmai státusra, illetve a presztízsre utal,

OBJ4 - MUNKÁBA ÁLLÁS IDEJE: milyen gyorsan sikerült munkát találnia a vizsgált személynek,

OBJ5 - FIZETÉs: fizetés mértékének megállapítását szolgálta.

A szubjektív sikeresség indikátorai

SZUBJ1 - A MUNKA SZEMÉLYI ÉS TÁRGYI KÖRÜLMÉNYEIVEL való elégedettség,

SZUBJ2 - A MUNKA SZAKMAI, TARTALMI RÉSZÉVEL való elégedettség,

${ }^{4}$ Heslin [2005a], [2005b], Gunz-Mayrhofer [2011], Kazár-Kürtösi [2017], Kiss [2014], [2016], KissBarizsné Hadházi [2016], Veroszta [2011] és Vinogradov [2017]. 
SZUBJ3 - SZAKMAI ELŐMENETELLEL, KARRIERÉPÍTÉSSEL való elégedettség,

SZUBJ4 - SZAKMAI PRESZTÍZZSEL való elégedettség,

SZUBJ5 - JÖVEDELEMMEL ÉS JUTTATÁSOKKAL való elégedettség.

Összességében öt objektív és öt szubjektív mutató azonosítása történt meg. A többi kutatáshoz képest eltérés, hogy az objektív mutatók között megjelenik az alkalmazotti létszám, a vállalati méret és a beosztás, a szubjektív mutatók között pedig a munka tárgyi és személyi körülményei.

Ưgy gondoljuk, hogy a lehetőségekhez mérten minél több válaszadó biztosítja a vizsgálódás érvényességét, ezért nem szűkítettük tovább az elemszámot a mintában lévő kiugró értékek trimmelésével. Ehelyett annak érdekében, hogy meg lehessen ítélni az egyes sikerességi tényezők hatását, az aránytalanságokat egy pontozási rendszer segítségével csökkentettük. Mindegyik (öt objektív és öt szubjektív) tényezőt 1-4-es intervallumon pontoztuk, ebből adódóan összesen 40 pontot lehet elérni a karriersikeresség megítélésekor. Példaként megemlítjük, hogy az objektív tényezők közül a jövedelemnél a vonatkozó év bruttó szellemi foglalkozásúak nettó fizetési kvartilisei alkotják a pontszámokat (OBJ5), míg a vezetői felelősség mutatójánál (OBJ1) az alkalmazotti/beosztotti létszám és a vállalati méret esetében két dimenzió szerint alakítottuk ki a kritériumokat (2. táblázat), továbbfejlesztve Veroszta [2011] megközelítését.

\section{2. táblázat}

A vállalati méret és a beosztottak száma szerint kialakított objektív karrierpontok

\begin{tabular}{lccc}
\hline & \multicolumn{3}{c}{ Alkalmazott/beosztott } \\
\cline { 2 - 4 } & nincs & $1-9$ & 10 vagy több \\
\hline Önfoglalkoztató & 4 & - & - \\
$2-9$ fö & 3 & 4 & - \\
$10-49$ fö & 2 & 3 & 4 \\
$50-249$ fö & 2 & 2 & 4 \\
$250-999$ fö & 1 & 2 & 4 \\
1000 fö felett & 1 & 1 & 4 \\
\hline
\end{tabular}

Forrás: saját szerkesztés DPR - Frissdiplomások 2011-2014. évi adatai alapján.

A szubjektív tényezőknél az 1-4-es kategóriák szimplán értékelési pontokká történő konvertálását követően adódott a karrier sikerességét meghatározó összpontszám. A fö számok kialakítása során nem történt súlyozás, ahogyan a vizsgált hazai és nemzetközi cikkekben is azonos súllyal vették figyelembe az egyes tényezőket. A Függelékben közöljük a szubjektív és objektív karriersikeresség tényezőinek pontértékeit.

Az egyes változók leíró statisztikája alapján (3. táblázat) jól látható, hogy a szubjektív sikeresség változói esetében jellemzően magasabb átlagok azonosíthatók, mint az objektív sikeresség változói esetében. Az előbbieknél a medián, módusz is 3 -as értéket vesz fel, míg az utóbbiaknál nagyobb szóródás azonosítható. Az OBJ4-nél a végzettek 90 százaléka jellemzően három hónapon belül talál munkát, míg a hat hónapon 
túli elhelyezkedés már 1 százalék alatti, ezért magasak a pontszámok. Az OBJ1 és овJ3 esetében a frissen végzetteknél alacsonyabb az esély egy relatíve magas pozíció betöltésére, illetve a mások irányítására, erre vezethető vissza az alacsony pontszám.

3. táblázat

Az objektív és szubjektív sikeresség indikátorai, valamint az alkotóelemek leíró statisztikái

\begin{tabular}{lrccccc}
\hline & Átlag & Medián & Módusz & Szórás & Csúcsosság & Ferdeség \\
\hline OBJ1 & 1,80 & 2 & 1 & 0,91 & 0,05 & 0,96 \\
OBJ2 & 2,91 & 3 & 3 & 0,71 & 1,26 & $-0,87$ \\
OBJ3 & 1,33 & 1 & 1 & 0,72 & 3,58 & 2,16 \\
OBJ4 & 3,71 & 4 & 4 & 0,66 & 4,91 & $-2,35$ \\
OBJ5 & 2,29 & 2 & 2 & 1,08 & $-1,05$ & 0,46 \\
SZUBJ1 & 3,17 & 3 & 3 & 0,72 & 0,43 & $-0,77$ \\
SZUBJ2 & 3,11 & 3 & 3 & 0,81 & 0,28 & $-0,77$ \\
SZUBJ3 & 2,76 & 3 & 3 & 0,92 & $-0,71$ & $-0,32$ \\
SZUBJ4 & 2,94 & 3 & 3 & 0,86 & $-0,28$ & $-0,54$ \\
SZUBJ5 & 2,71 & 3 & 3 & 0,86 & $-0,51$ & $-0,30$ \\
$\sum$ SZUBJ & 14,68 & 15 & 15 & 3,21 & 0,25 & $-0,59$ \\
¿оBJ & 12,04 & 12 & 11 & 2,11 & 0,81 & 0,53 \\
\hline
\end{tabular}

Forrás: saját szerkesztés DPR - Frissdiplomások 2011-2014. évi adatai alapján.

Összességében az elméleti közepet (5-20-as értékek) a szubjektív sikeresség mutatója esetében meghaladja az átlag, míg az objektívnél alatta van. Számításaink szerint az elméleti közép alapján a szubjektív sikerességnél 76,7 százalék, míg az objektív sikerességnél 36,4 százalék tekinthető sikeresnek. Amennyiben az átlagértékek jelentik a viszonyítási alapot, akkor a szubjektív sikerességnél 55 százalék, míg az objektív sikerességnél 36,4 százalék sikeres az átlagot meghaladóan.

Az egyes tényezők egymással való összefüggésének ellenőrzését Pearson-féle korrelációszámítással végeztük el. A 4. táblázat jól mutatja, hogy a szubjektív tényezők között közepes és pozitív az összefüggés, míg az objektív tényezők esetében az OBJ1 és OBJ3 közötti közepes kapcsolatot kivéve gyenge összefüggések figyelhetők meg, továbbá az OBJ1 és OBJ5 között ellentétes a hatás (ez az eredmény a változók sajátosságaiból adódik). A két karriersikerességi mutató között 0,25-os, gyenge kapcsolat azonosítható, ami megegyezik Seibert és szerzőtársai [2001] megállapításaival.

A vizsgálathoz alkalmazott módszertan, az OLS lineáris regresszió melletti választást azt támasztja alá, hogy a sikeresség mértékét befolyásoló tényezők egyedi hatásai kiszürhetők, azaz egy-egy tényezőnek a többi ceteris paribus változatlansága melletti befolyásoló ereje mutatható ki a kontrollváltozóhoz képest. Az egyenlet:

$Y=\beta_{0}+\beta_{1} X_{1}+\beta_{2} X_{2}+\beta_{3} X_{3}+\ldots+\beta_{22} X_{22}+\varepsilon$

$Y$ a szubjektív és objektív sikeresség függő változója, $X_{1}-X_{22}$ a lineáris regresszió független változói, $\varepsilon$ hibatag. 


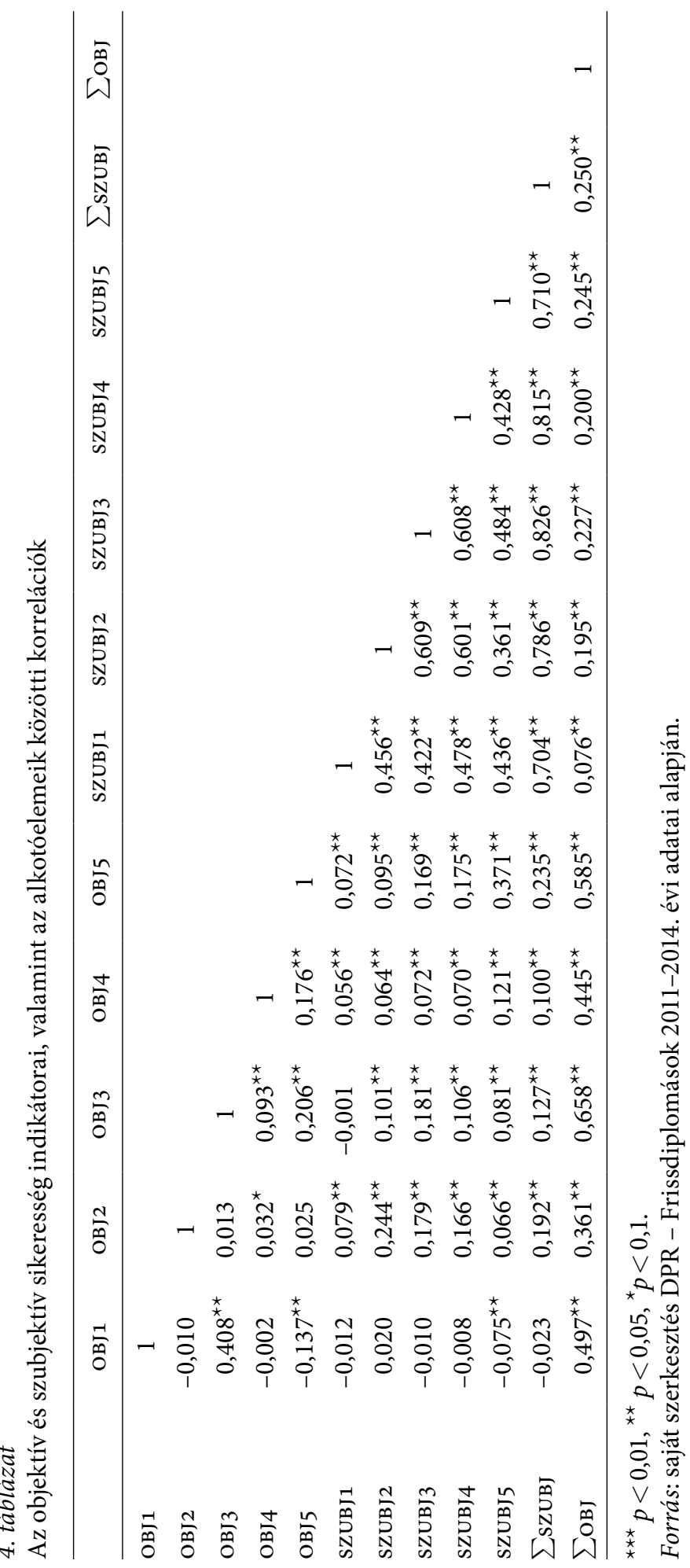


$\mathrm{Az}$ (1) egyenlet alapján a lineáris regresszió független változói:

- intézménytípus (Hrubos [2012] alapján)

- munkarend

- képzési forma

- a végzés és a kitöltés között eltelt idő

- a tanulmányi eredmény és a többi hallgató eredményéhezvaló viszonyának interakciója

- a tanulmányok során a területhez kapcsolódó és nem kapcsolódó, valamint a külföldi munkavégzés

- a tanulmányok során önmagáról alkotott kép és az abszolutóriumkori munkaviszony interakciója

- a munka során a tanulmányok alkalmazásának mértéke

- a munkához szükséges tanulmányi szint és a végzettség formájának interakciója

- a munkahely köz- és magántulajdoni aránya, a magyar-külföldi tulajdoni viszony

- a munkahely településtípusa és régiója

- nem

- családi állapot

- az apa és az anya legmagasabb iskolai végzettsége

- családon belül hasonló végzettségü rokon

A független változók kiválasztásakor egyrészt a tanulmányi sajátosságokat, másrészt a munkahelyi elemeket, harmadrészt pedig a szociodemográfiai háttértényezőket vettük figyelembe - összhangban a korábban bemutatott karriersiker értékelését és értelmezését befolyásoló tényezőkkel.

\section{Az elemzés eredménye}

Az (1) egyenletbe bevont összes független változó nominálisnak (illetve ordinálisnak) tekinthető, így kétértékű változóként (dummy) kell szerepeltetnünk őket. Az OLS módszertanából adódik, hogy a kétszeri (szubjektív és objektív sikeresség) futtatás eredményeként a szignifikáns független változó standard $B$-értékei úgy értelmezhetők, hogy az adott változó 1 százalékos változása a karriersikerességet milyen mértékben befolyásolja (az 5. táblázatban zárójelben látható) referenciaváltozóhoz képest. A lineáris regresszió lefuttatásához szükség volt az adatok megbízhatóságának vizsgálatára: a változók egymástól lineárisan függetlenek, az értékeik rögzítettek, nem változnak mintáról mintára, mérési hibát nem tartalmaznak, és nem korrelálnak a hibatényezővel, a hiba normális eloszlást követ. A szükséges elemzések elvégzését követően kijelenthető, hogy egyik feltételnél sem található kizáró érték. A multikollinearitás vizsgálata során megállapítható, hogy egy változó esetében sem azonosítható veszélyes mérték, a VIF-érték mindegyiknél megfelelö, a Durbin-Watson-próba eredménye (szubjektív: 1,951, objektív: 1,887) sem mutat veszélyes szintű korrelációt (Babbie [2016]).

\footnotetext{
${ }^{5}$ A varianciainflációs tényező (Variance Inflator Factor, VIF) értéke a multikollinearitás mérésére szolgál: ha értéke kisebb, mint 2, akkor nem áll fenn multikollinearitás, ha 2 és 10 közötti értéket vesz fel, akkor nem zavaró, 10 felett pedig erős, káros a mértéke.
} 


\section{5. táblázat}

A szubjektív és objektív karriersikeresség OLS-regressziói

$\frac{\text { Szubjektív }}{\underset{B}{\text { Standard }} p} \frac{\text { Objektív }}{\substack{\text { Standard } \\ B}} p$

\section{INTÉZMÉNYTÍPUS}

Speciális, szükebb képzési profilú (döntően) föiskolák $\quad-0,045 \quad 0,001 \quad-0,006 \quad 0,627$ (referenciakategória: klasszikus egyetemek)

VÉGZÉS ÉVE ÓTA ELTELT IDŐ

(referenciakategória: egy éve végzett)

Három éve végzett

\begin{tabular}{llll}
$-0,017$ & 0,269 & 0,089 & 0,000 \\
$-0,024$ & 0,135 & 0,156 & 0,000 \\
\hline
\end{tabular}

Öt éve végzett

TANULMÁNYI EREDMÉNY, ABSZOLÚT $\times$ RELATÍV

(referenciakategória: jó $\times$ olyan, mint a többieké)

Elégséges $\times$ sokkal rosszabb

\begin{tabular}{rrrr}
0,009 & 0,511 & 0,028 & 0,025 \\
0,026 & 0,055 & 0,029 & 0,021 \\
0,005 & 0,736 & $-0,026$ & 0,044 \\
$-0,004$ & 0,770 & 0,034 & 0,014 \\
\hline 0,011 & 0,461 & 0,091 & 0,000
\end{tabular}

Elégséges $\times$ olyan, mint a többieké

Jó $\times$ valamivel rosszabb

Jeles, kiváló $\times$ sokkal jobb

TANULMÁNYOK SORÁN A TERÜLETHEZ KAPCSOLÓDÓ

MUNKAVÉGZÉS = igen (referenciakategória: nem)

KÜLFÖLDI MUNKAVÉGZÉS = igen

$0,020 \quad 0,162$

$0,029 \quad 0,029$

(referenciakategória: nem)

TANULMÁNYOK ALATT MINEK TEKINTETTE MAGÁT $\times$ ABSZOLUTÓRIUMKORI MUNKAVÉGZÉS (referenciakategória: főfoglalkozású dolgozó, és dolgozott)

Főfoglalkozású diák $\times$ dolgozott

$\begin{array}{llll}0,025 & 0,462 & -0,097 & 0,000 \\ 0,010 & 0,795 & -0,249 & 0,000 \\ 0,032 & 0,371 & -0,045 & 0,002\end{array}$

Főfoglalkozású diák $\times$ nem dolgozott

Főfoglalkozású dolgozó $\times$ nem dolgozott

0,032

MUNKA SORÁN A TANULMÁNYOK ALKALMAZÁSÁNAK MÉRTÉKE

(referenciakategória: közepes mértékben)

Egyáltalán nem

$\begin{array}{rrrr}-0,102 & 0,000 & -0,140 & 0,000 \\ -0,040 & 0,011 & -0,104 & 0,000 \\ 0,057 & 0,000 & 0,044 & 0,002 \\ 0,096 & 0,000 & 0,062 & 0,000\end{array}$

Kevéssé

Nagymértékben

$0,096 \quad 0,000$

KÉPZÉSI FORMA $\times$ MUNKÁHOZ SZÜKSÉGES SZINT

(referenciakategória: föiskolai vagy alapképzéses diploma $\times$ föiskolai vagy alapképzéses diploma)

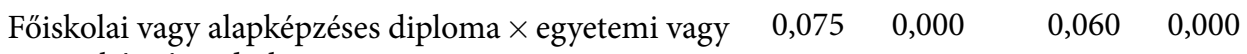
mesterképzéses diploma

Főiskolai vagy alapképzéses diploma $\times$ nem igényel $\quad \begin{array}{llll}-0,244 & 0,000 & -0,158 & 0,000\end{array}$ felsőfokú végzettséget 


\begin{tabular}{|c|c|c|c|c|}
\hline & \multicolumn{2}{|c|}{ Szubjektív } & \multicolumn{2}{|c|}{ Objektív } \\
\hline & $\begin{array}{l}\text { Standard } \\
\qquad B\end{array}$ & $p$ & $\begin{array}{l}\text { Standard } \\
\quad B\end{array}$ & $p$ \\
\hline $\begin{array}{l}\text { Egyetemi vagy mesterképzéses diploma } \times \text { egyetemi } \\
\text { vagy mesterképzéses diploma }\end{array}$ & 0,054 & 0,002 & 0,068 & 0,000 \\
\hline $\begin{array}{l}\text { Egyetemi vagy mesterképzéses diploma } \times \text { föiskolai } \\
\text { vagy alapképzéses diploma }\end{array}$ & $-0,073$ & 0,000 & $-0,011$ & 0,458 \\
\hline $\begin{array}{l}\text { Egyetemi vagy mesterképzéses diploma } \times \text { nem } \\
\text { igényel felsőfokú végzettséget }\end{array}$ & $-0,085$ & 0,000 & $-0,059$ & 0,000 \\
\hline $\begin{array}{l}\text { MUNKAHELY KÖZ- ÉS MAGÁNTULAJDONI ARÁNYA } \\
\text { Teljes mértékben állami/önkormányzati } \\
\text { tulajdonú (referenciakategória: teljes mértékben } \\
\text { magántulajdon) }\end{array}$ & $-0,062$ & 0,000 & $-0,180$ & 0,000 \\
\hline \multicolumn{5}{|c|}{ MunKahELY TULAJDONVISZONYA (referenciakategória: teljes mértékben külföldi tulajdonú) } \\
\hline Teljes mértékben magyar tulajdonú & $-0,060$ & 0,001 & 0,146 & 0,000 \\
\hline Részben magyar tulajdonú & $-0,005$ & 0,740 & 0,027 & 0,049 \\
\hline $\begin{array}{l}\text { MUNKAHELY TELEPÜLÉSTÍPUSA } \\
\text { Külföld (referenciakategória: főváros) }\end{array}$ & 0,020 & 0,191 & 0,160 & 0,000 \\
\hline \multicolumn{5}{|c|}{ MuNKAHELY RÉGIÓJA (referenciakategória: Közép-Magyarország) } \\
\hline Közép-Dunántúl & $-0,042$ & 0,043 & $-0,067$ & 0,000 \\
\hline Dél-Dunántúl & $-0,048$ & 0,034 & $-0,057$ & 0,007 \\
\hline Észak-Magyarország & $-0,028$ & 0,107 & $-0,074$ & 0,000 \\
\hline Észak-Alföld & $-0,024$ & 0,230 & $-0,064$ & 0,001 \\
\hline Dél-Alföld & $-0,036$ & 0,120 & $-0,089$ & 0,000 \\
\hline $\begin{array}{l}\text { NEM } \\
\text { Férfi (referenciakategória: nő) }\end{array}$ & $-0,007$ & 0,608 & 0,100 & 0,000 \\
\hline $\begin{array}{l}\text { APA LEGMAGASABB ISKOLAI VÉGZETTSÉGE } \\
\text { legfeljebb } 8 \text { általános a diák } 14 \text { éves korában } \\
\text { (referenciakategória: felsőfokú) }\end{array}$ & $-0,018$ & 0,227 & 0,032 & 0,023 \\
\hline $\begin{array}{l}\text { ANYA LEGMAGASABB ISKOLAI vÉGZETTSÉGE } \\
\text { szakmunkásképzö, szakiskola (érettségi nélkül) a diák } \\
14 \text { éves korában (referenciakategória: felsőfokú) }\end{array}$ & 0,029 & 0,092 & $-0,039$ & 0,014 \\
\hline$\overline{R^{2}}$ & \multicolumn{2}{|c|}{0,182} & \multicolumn{2}{|c|}{0,301} \\
\hline Korrigált $R^{2}$ & \multicolumn{2}{|c|}{0,168} & \multicolumn{2}{|c|}{0,289} \\
\hline F-érték & \multicolumn{2}{|c|}{12,790} & \multicolumn{2}{|c|}{24,850} \\
\hline p-érték & \multicolumn{2}{|c|}{0,000} & \multicolumn{2}{|c|}{0,000} \\
\hline$N$ & \multicolumn{2}{|c|}{4515} & \multicolumn{2}{|c|}{4515} \\
\hline Konstans & \multicolumn{2}{|c|}{15,270} & \multicolumn{2}{|c|}{12,203} \\
\hline
\end{tabular}

Forrás: saját szerkesztés DPR - Frissdiplomások 2011-2014. évi adatai alapján. 
Az OLS-regresszió olyan elemei jelennek meg a tanulmányban, amelyek nem tekinthetők a futtatás szempontjából kontrollváltozónak. ${ }^{6}$ A modell megbízhatóságához kapcsolódóan a táblázatból látható, hogy a korrigált $R^{2}$-értékek a társadalomtudomány területén magasnak számítanak (szubjektív $R^{2}=16,8$ százalék, objektív $R^{2}=28,9$ százalék). Ez azt jelenti, hogy természetesen számos egyéb tényező befolyásolja a karriersikerességet, ugyanakkor a bevont változók a karriersikeresség egy szignifikáns részét megmagyarázzák. A modellek létezése bizonyított az $F$ - és a $p$-értékek alapján.

EGYÉNI DEMOGRÁFIAI TÉNYEZŐK HATÁSA A SIKERESSÉGRE • A nemek közötti különbségek vizsgálata szignifikáns eredményt mutat az objektív sikerességnél, ami azt jelenti, hogy a férfiak a nőkhöz képest 10,0 százalékkal magasabb pontot kapnak. Ez többek között a fizetésben meglévő jól ismert különbségekre és a frissdiplomások között is meglévö üvegplafonhatásra utal (Cotter és szerzőtársai [2001]). Az különösen pozitívnak tekinthető, hogy a szubjektív sikerességnél ilyen szempontú eltérés nem látható, azaz a nők és a férfiak egyenlőek a többi tényező hatását kiszürve.

A szülők iskolai végzettségének a közép- és felsőfokú választásokat befolyásoló ereje 14 éves korban lehet a legnagyobb (Nyüsti-Veroszta [2015]). A Diplomás Pályakövető Rendszer rákérdez ennek meglétére, és a két sikerességi dimenzió alapján megállapítható, hogy ez minimálisan befolyásolja a végzettek értékeit. Mindkét szignifikáns hatás az objektív elemhez kapcsolódik. A felsőfokúhoz képest legfeljebb nyolc általános képzettségű apa esetében 3,2 százalékos előny látható, míg az ugyanebben az összefüggésben az érettségi nélküli középfokú végzettségü anyánál 3,9 százalékos hátrány mutatható ki. A kutatások azt mutatják, hogy az anya végzettsége számít (lásd például Korupp és szerzőtársai [2002]), azonban itt is pozitívum, hogy csak egy tényező esetében van szignifikáns hátrány. Az apáknál kimutatott előny magyarázata további vizsgálatot igényel.

A gazdaságtudományi területen végzettek körében a családon belüli hasonló végzettség megléte vagy hiánya nem eredményez szignifikáns eltérést. Ez valószínüsíthetően más eredményre vezet más területek esetében.

EMBERITŐKE-ELEMEK BEFOLYÁSA A SIKERESSÉGRE • Az intézmény típusa esetében egy tényezőnél volt szignifikáns különbség. A szükebb képzési profilú főiskolán végzettek 4,5 százalékkal alacsonyabb szubjektív sikerességet tapasztaltak a klaszszikus egyetemeken végzettekhez képest, ugyanakkor objektív sikeresség tekintetében nincs különbség. Ez arra utalhat, hogy a nagyobb fokú specializáció nem ad lehetőséget az időközben esetlegesen azonosított változtatási szándék megvalósítására, és a korábban választott pályát kell folytatni.

A végzés éve óta eltelt időt tekintve az objektív sikeresség esetében az egy éve végzettekhez képest a három éve végzettek 8,9 százalékkal, az öt éve végzettek 15,6 százalékkal magasabb értéket értek el. Ez az eredmény várható volt, hiszen az

\footnotetext{
${ }^{6}$ A teljes eredményt kérésre a szerzők az olvasók rendelkezésére bocsátják.
} 
idő előrehaladtával a szervezeten belüli ranglétrán való előrehaladás valószínűsíthető. Ezzel szemben pozitívnak tekinthető, hogy a szubjektív sikerességet nem az idő határozza meg, azaz a belső értékek szerint alakult ki az elégedettség mértéke.

A tanulmányi eredmény és a relatív tanulmányi eredmény interakciójában az látható, hogy a szubjektív sikerességre egy esetben sincs szignifikáns hatással a ,jó $\times$ olyan, mint a többiek” eredménye referenciakategóriához képest. Az objektív sikeresség esetében két trend figyelhető meg. Egyrészt az elégséges tanulók (akiknek sokkal rosszabb vagy olyan az eredménye, mint a többieké) 2,8 százalékkal, illetve 2,9 százalékkal magasabb objektív karriersikerességet értek el. Ez azt jelenti, hogy ők azok, akik úgy gondolják, a tanulmányok során csak bizonyos területekre kell koncentrálni, illetve csupán meg kell szerezni a diplomát, de a valóságban más tényezök számítanak. A másik trend pedig azokra vonatkozik, akik úgy gondolják, hogy mindenképpen szükséges jó jegyeket is szerezni. A jól és a valamivel rosszabbul teljesítőknél 2,6 százalékkal alacsonyabb, míg a jeles, kiváló, de a többiekhez képest sokkal jobb eredményt elérők 3,4 százalékkal magasabb objektív karriersikerességet tapasztaltak. Ez azt jelenti, hogy szerintük ahhoz, hogy sikeresebbek lehessenek, szükséges az általános tudás, illetve a különböző területek egymásra hatása. Vagyis ez értelmezhető úgy is, hogy megéri jobban tanulni, mert például jobban fizető és magasabb beosztás érhetö el általa.

A tanulmányok időszakához kapcsolódó munkavégzés kérdéskörének eredményei megerősítik a modellalkotás helyességét. Egyrészt a külföldi munkavégzés az objektív sikerességet tekintve 2,9 százalékkal magasabb értéket mutat, ami azért kedvezö, mivel a külföldi munkatapasztalat jellemzően jobb pozíciót tesz lehetővé a munkaerőpiacon (Dusa [2015]). A tanulmányok alatt végzett nem szakmai munka nem szignifikáns egyik szempont szerint sem, ami arra utal, hogy ez jellemzően a megélhetés kérdésköréhez kapcsolódik, hiszen a szakmai munka esetében az objektív sikerességet tekintve 9,1 százalékkal magasabb karriersikeresség látható.

Ugyanezt erösíti meg a tanulmányok alatt a hallgatóknak önmagukról alkotott képe, illetve az abszolutóriumkor meglévő munka interakciója. A fóállású dolgozó, aki rendelkezett munkával referenciakategóriához képest a szubjektív sikeresség egy esetben sem mutat eltérést, míg az objektív sikeresség minden tényezőjénél szignifikáns. Annak a föfoglalkozású diáknak, aki dolgozott az abszolutóriumkor, 9,7 százalékkal alacsonyabb, míg aki nem dolgozott, 24,9 százalékkal alacsonyabb az objektív karriersikeressége. Azon fóállású dolgozó esetében, aki az abszolutóriumkor nem dolgozott, negatív az eltérés, bár kisebb mértékű ( $-4,5$ százalék). Ez már a munka világa felé való eltolódást is mutatja. Fontos kiemelni, hogy ez nem a munkarend formájának a függvénye, hiszen a nappali és levelező szakos hallgatók között semmilyen különbség nem azonosítható.

A tanulmányok hasznosithatósága, illetve a kapcsolódás örök kérdés a felsőoktatás hatékonyságának megítélésekor (Kiss-Barizsné Hadházi [2016]), a DPR-ben is megjelenik ez a kérdés. A munka során a tanulmányok konkrét hasznosíthatósága mindkét sikeresség esetében szignifikáns mindegyik tényező szerint a közepes mértékben hasznosuláshoz képest. A szubjektív sikeresség esetében azonban fontos különbséget lehet felfedezni az objektívhez képest. Az alacsonyabb szintü 
hasznosulás kisebb hátrányt (-10,2 százalék), míg a nagyobb mértékủ nagyobb fokú (9,6 százalék) előnyt jelent, mint az objektív sikeresség esetében (rendre $-14,0$ százalék és 6,2 százalék). Azaz a hasznosulás esetében a szubjektív sikeresség megélése magasabb fokú pozitív és kisebb mértékủ negatív eltérést eredményez, mivel más, értékhez kapcsolódó tényezők is szerepet játszanak a percepcióban. Az objektív sikeresség esetében éppen ellentétes a hatás, azaz a negatív irányú eltérés nagyobb mértékü, mivel valószínűleg alacsonyabb jövedelemmel társul, miközben a nagyobb fokú kapcsolódás csak kisebb előnyt jelent, mivel szintén más tényezők befolyásolják például a pozíció vagy a fizetés meglétét.

Az elöző kérdéshez szorosan kapcsolódik a munka által igényelt képzettségi szint, illetve a képzési forma interakciója. A föiskolai alapdiplomás végzettség, illetve a munkahely által igényelt, ugyanilyen szintü végzettséghez képest mindkét karriersikeresség esetében szignifikáns különbséget okoz a végzettséghez képest magasabb elvárásnak megfelelő foglalkoztatás, illetve alacsonyabbat a végzettséghez képest alacsonyabb munkakörben való foglalkoztatás. A szubjektív sikerességet nagyobb mértékben érinti negatívan az utóbbi: föiskolai alapszakos diploma esetében a felsőfokú végzettséget nem igénylő munkakörben 24,4 százalékkal alacsonyabb az érték, mint a hasonló objektív sikerességnél. Ugyanez látható az egyetemi mesterszakos diplomás végzettség esetében a föiskolai alapdiplomás végzettséget igénylő munkakörben (szubjektív sikerességnél -7,3 százalék, míg az objektív sikerességnél nem szignifikáns), illetve a végzettséget nem igénylő munkakörben is (szubjektív sikerességnél -8,5 százalék, objektív sikerességnél -5,9 százalék). Ez összecseng azzal, amire Balogh-Sipos [2019] is felhívja a figyelmet, hogy az emberitöke-beruházás elmélete szerint a mesterszak elvégzése gyorsabb elhelyezkedést és magasabb jövedelmi szintet eredményezhet.

SZERVEZETI JELLEMZÖK BEFOLYÁSA A SIKERESSÉGRE • A munkahely állami vagy magántulajdonú volta a teljesen magánkézben lévőkhöz képest a tisztán állami tulajdon esetében mutat szignifikáns, ráadásul egységesen negatív irányú eltérést. Az objektív sikerességnél ez nagyobb mértékü, ami azt is jelenti, hogy az alacsonyabb fizetés, a merevebb struktúra és előrelépés miatt erőteljesebb a negatív hatás (-18,0 százalék), miközben a szubjektív esetben „csupán” 6,0 százalékkal alacsonyabb a sikeresség mértéke.

A tulajdonviszony magyar vagy külföldi volta a tisztán külföldihez képest a teljesen magyar tulajdon esetében 14,6 százalékkal magasabb, míg a részben magyar tulajdonnál 2,7 százalékkal magasabb eredményt ad az objektív karriersikeresség esetében. Ezzel szemben a szubjektív 0,6 százalékkal alacsonyabb értéket ad a teljes mértékben magyar tulajdonúhoz képest, és nem szignifikáns a részben magyar tulajdonú esetében. Ez részben arra vezethető vissza, hogy a saját vállalkozás (ami valószínűsíthetően magyar) magas objektív karriersikerességet eredményez, ezért előnyt generál a külföldivel szemben, továbbá a külföldi tulajdon esetében nehezebb elérni a magas pontozást. Ezt támasztja alá az is, hogy a munkahely településtípusánál kizárólag az objektív sikerességnél látható szignifikáns eltérés a fövároshoz képest, mégpedig a külföldön dolgozók 16,0 százalékkal magasabb értéket érnek el. A településtípusnál nem látható máshol szignifikáns különbség, ami azt 
jelenti, hogy a régiók között lehet nagyobb eltérést azonosítani. A régiók szempontjából Közép-Magyarországhoz képest az objektív sikerességnél mindegyik régió esetében hátrány azonosítható (ez részben a fizetésbeli különbségekre vezethető vissza). Ezzel szemben a szubjektív sikerességnél csak a Közép-Dunántúl és a DélDunántúl régiók mutatnak alacsonyabb szintet ( $-4,2$ százalék és $-4,8$ százalék), azaz itt a munkahely elhelyezkedése nem döntő tényező.

\section{Következtetések}

Összességében a gazdaságtudományi területen végzettek közül az elméleti közép alapján a szubjektív sikerességnél 76,7 százalék, míg az objektív sikerességnél 36,4 százalék tekinthető sikeresnek. Az idézett szakirodalmakra (például Callanan [2003]) visszagondolva ez nem meglepő, mivel idő kell az objektív sikertényezők felhalmozásához. A vizsgálat célpontját pedig az 1-5 éve végzettek képezték, akik még viszonylag rövid ideje vannak a munkaerőpiacon. A karriersikeresség általunk megalkotott koncepcionális modellje jó alap lehet az egyes tudományterületek végzettjeinek összehasonlítására, de akár különböző intézmények frissdiplomásainak összevetésére is.

A 4515 fő frissdiplomáson végzett elemzésünk többnyire megerősítette az eddigi szakirodalmi tanulságokat, azaz a demográfiai vagy az emberi tökéhez köthető tényezők, valamint a munkáltatói jellemzők többségében az objektív siker realizálásához járulnak hozzá.

Megállapítottuk, hogy a tanulmányi eredmény többiekhez képesti viszonya szerint a jobb eredménnyel végzettek objektív szempontból sikeresek. Ez értelmezhető úgy, hogy megéri jobban tanulni, mert például jobban fizetett és magasabb beosztás érhető el. Ugyancsak látható, hogy a tanulmányok alatt végzett nem szakmai munka nem szignifikáns egyik szempont szerint sem, ami arra utal, hogy ez jellemzően a megélhetés kérdésköréhez kapcsolódik, hiszen a tanulmányok alatt végzett szakmai munka esetében magasabb objektív sikeresség realizálható.

A szubjektív sikeresség nem függvénye a végzés éve óta eltelt időnek, és így közvetve a kornak, azaz már fiatalon is elérhetö. Fontos következtetésünk, hogy a közepes tanulmányi eredmények a szubjektív siker megvalósításában nagyobb szerepet játszanak, mint a jobb eredmények, azaz a szubjektív siker nem a jó tanulók kiváltsága: gyengébben teljesítő társaik is elérhetik, akár még magasabb arányban is megélik azt. Bár a nemek közötti különbségek vizsgálata azt mutatta, hogy a férfiak magasabb szintű objektív sikert képesek elérni, mint a nők, viszont szubjektív tekintetben hasonló sikereket realizáltak.

Végül pedig mindkét sikeresség esetében szignifikáns jelentőségü, hogy a munka során az egyén tudja hasznosítani korábbi tanulmányait. Az alacsonyabb szintü hasznosulás kisebb hátrányt és nagyobb előnyt jelent a szubjektív sikeresség mutatója alapján, mint az objektív sikeresség mutatója alapján. Vagyis a belső egyéni értékelés szempontjából fontos, hogy olyan munkát találjon az egyén, amely a tanulmányaihoz jól köthető. 


\section{A kutatás korlátai}

A Diplomás Pályakövető Rendszer Frissdiplomások adatbázisaiban a válaszadás önkitöltős, amit szubjektív torzítás befolyásolhat. Továbbá 15-20 százalékos válaszadási arány a jellemző, ami intézményenként és megkérdezési időszakonként ingadozik. E tényezők hatását egyrészt a tanulmányban alkalmazott megközelítéssel lehet csökkenteni: jelentősen szükítettük az életkor és a tudományterületek szerinti adatállományt, ezáltal a minta egyrészt sokkal homogénebb lett, másrészt pedig más kutatások eredményeivel össze lehet vetni. Ez a mi forrásfeldolgozásunk alapján nem lehetséges, ugyanakkor érdemes kiemelni Sipos [2018] disszertációját, amely az AAEben szereplő objektív bruttó fizetési adatokkal vetette össze a DPR Frissdiplomások szubjektív nettó fizetési adatait, és nem talált különbséget. Ez alapján feltételezhetö, hogy ha egy ilyen érzékeny adatnál nem torzítanak tudatosan a válaszadók, akkor a többi kérdés esetében is megbízhatónak tekinthetők a válaszok.

Emellett ki kell emelni, hogy bár a DPR sok területre kérdez rá, a szubjektív sikeresség tényezőinél a korreláció közepes, míg az objektív sikeresség tényezőinél ez gyenge, illetve eltérő irányú hatás is azonosítható.

\section{A kutatási eredmények hasznositási területei}

Tanulmányunk fontos kiindulópontként szolgálhat a kutatók számára, kiemelnénk a karriersikeresség frissdiplomások körében alkalmazott pontozási rendszerére épülö vizsgálatát, amilyet még nem végeztek magyar adatokon. A módszertani építkezés és a mérési modell lehetőséget biztosít az egyéb területeken végzettek körében való elemzésre is, illetve ennek köszönhetően azonosítani lehet az egyes szakmákban tanuló felsőoktatási hallgatók igényeit. Ezáltal további információk nyújthatók az intézmények által kibocsátott diplomások sikerességéröl, illetve azt is lehet vizsgálni, hogy miben nyújtanak eltérő lehetőségeket a karriersikerességhez kapcsolódóan a különbözö típusú felsőoktatási intézmények (Hrubos [2012]).

Tanulmányunk új megközelítése segítheti az oktatáspolitika és a felsőoktatási intézmények döntéshozóit is. A munkaerőpiaci megfeleltethetőséget, illetve a felsőoktatás és a munkaerőpiac elvárásainak szorosabb összekapcsolódását sokszor a tanulmányi eredményekkel, a lemorzsolódás által veszélyeztetettek objektív tényezők általi meghatározottságával vizsgálják az érintettek. Az eredmények alapján ezek legfeljebb objektív tényezőknek tekinthetők, miközben egyértelmüen látható, hogy a szubjektív elemek is jelentős szerepet töltenek be a hallgatói életutakban. Szignifikáns a kapcsolat az objektív és a szubjektív sikeresség tényezői között. Hiába szerez egy hallgató magas szintű szakmai tudást és kompetenciát, ha az adott szak esetleg nem megfelelő a számára. Ebből adódóan nagyobb hangsúlyt kell fektetni a „puha készségek” fejlesztésére, lehetőséget kell biztosítani az önismeretre, az önmaguk megértésére. Erre kiváló platformot biztosítanak a tehetségfejlesztő központok/tehetségpontok. Ki kell emelni, hogy az eredmények azt is mutatják, hogy nem feltétlenül és kizárólag a jó képességü hallgatókat kell bevonni 
a programokba, sőt a közepes képességűek jóval motiváltabbak, illetve jelentősebb fejlődés érhető el a velük való foglalkozás révén. Tehát nem csak a szűk elitre kell koncentrálni, hanem a kompetenciafejlesztés folyamatát széles körben, akár mindenkire ki kellene terjeszteni.

A felsőoktatásba jelentkezőknek, illetve a már ott tanuló hallgatóknak is hasznos információkat mutatnak az eredmények. Fontos tanulság, hogy a mesterszintü tanulmányok folytatása melletti döntés megéri a karrier és a fizetés szempontjából is, továbbá érdemes a tanulmányok alatt a szakmaterülethez kapcsolódó szakmai gyakorlatot (a gazdasági területen kötelezö szakmai gyakorlaton kívül) szerezni. Ez utóbbi elérhető például a kutatásba való bekapcsolódás, a tutori munka, a szakkollégiumi lét, illetve egyéb intézményi kezdeményezések révén. ${ }^{7}$ Végül az is fontos eredmény, hogy a másokénál jobb tanulmányi átlag magasabb szintủ objektív karriersikerességet jelent, ami áttételesen magasabb beosztást és fizetést is eredményezhet. Megéri befektetni az energiát a tanulmányokba, hiszen az ezáltal elérhető pénzbeli ösztöndíjak lehetőséget jelentenek arra is, hogy a gazdaságtudományi területen jellemző magas arányú finanszírozási kényszer miatt ne kelljen elvállalni a szakterülethez nem kapcsolódó munkát a tanulmányok ideje alatt.

\section{További kutatási irányok}

A jövőben tervezzük a kutatás korlátairól írottaknak megfelelően egyéb területek, illetve felsőoktatási intézménytípusok karriersikerességének vizsgálatát is. Az összehasonlítás lehetőséget biztosít a gazdaságtudományi területen végzetteknél azonosított sikerességi arányoktól való eltérések elemzésére is. Ez lehetőséget teremt az egyes szakmák számára legfontosabb befolyásoló tényezők azonosítására, és így az intézmények is képesek lehetnek megfelelőbb kompetenciafejlesztési szolgáltatást kialakítani.

A tanulmányunkban számos megközelítést vizsgáltunk meg a szubjektív és objektív karriersikeresség összefüggéseire vonatkozóan. Jelen megközelítést exploratív jellegűnek tekintve a logikai építkezésbe nem fért bele e dimenziónak mélyebb vizsgálata, ugyanakkor érdemes egy megismételhetö klaszterképzés (nem $k$-közepü) segítségével azonosítani a különböző karriersikerességi utakat. Ennek köszönhetően azonosítani lehet a jellemző életpályákat, illetve az intézményi döntéshozók számára ajánlani lehet még inkább személyre szabott hallgatói szolgáltatási csomagok kialakítását.

Az öt szubjektív és öt objektív tényező kiválasztása az elérhető nemzetközi és hazai irodalom alapján valósult meg. Ugyanakkor a felmérésben számos egyéb változó szerepel, amelyek esetleges bevonását többszörös validálás mellett kell megvizsgálni. Ez a folyamat hosszú időt igényel, továbbá az adatok többszöri átstrukturálását.

\footnotetext{
${ }^{7}$ Például a Pécsi Tudományegyetem Internship Centerében lehetőség van valós vállalati problémák megoldására egy félév során, heti rendszerességü ügyfélegyeztetés mellett.
} 


\section{Hivatkozások}

Abele, A. E.-Spurk, D.-Volmer, J. [2011]: The construct of career success: Measurement issues and an empirical example. ZAF, Vol. 43. No. 3. 195-206. o. https://doi.org/10.1007/ s12651-010-0034-6.

Alzyoud, A. A. Y. [2017]: The Predictors of Career Success. International Review of Management and Marketing, Vol. 7. No. 2. 22-26. o. https://pdfs.semanticscholar.org/d93e/ 6cddeb6fbe6792203c283898fd4dd2ce18f7.pdf.

Arthur, M. B.-Khapova, S. N.-Wilderom, C. P. M. [2005]: Career success in a boundaryless world. Journal of Organizational Behavior, Vol. 26. No. 2. 177-202. o. https://doi. org/10.1002/job.290.

AsPlund, G. [1988]: Women managers: changing organisational cultures. John Wiley, Chichester. BABbie, E. [2016]: The practice of social research. Cengage Learning, Andover.

BALOGH GÁBOR-Sipos NorberT [2019]: Pályakezdő közgazdászok bére a szakdiverzifikáció függvényében. Közgazdasági Szemle, 66. évf. 5. sz. 551-577. o. https://doi.org/10.18414/ KSZ.2019.5.551.

BARUCH, Y.-Bozionelos, N. [2010]: Career Issues. Megjelent: Zedeck, S. (szerk.): APA Handbook of Industrial and Organizational Psychology. Vol. 2. Selecting \& Developing members of the Organization. American Psychological Association, Washington, DC, 67-113. o. https://doi.org/10.1037/12170-000.

Blokker, R.-Akkermans, J.-Tims, M.-Jansen, P.-Khapova, S. [2019]: Building a sustainable start: The role of career competencies, career success, and career shocks in young professionals' employability. Journal of Vocational Behavior, Vol. 112. 172-184. o. https:// doi.org/10.1016/j.jvb.2019.02.013.

Callanan, G. A. [2003]: What price career success? Career Development International, Vol. 8. No. 3. 126-133. o. https://doi.org/10.1108/13620430310471032.

Carnevale, A. P.-Rose, S. J. [2012]: The convergence of postsecondary education and the labor market. Megjelent: Lane-Johnstone (szerk.) [2012] 163-190. o.

Cotter, D. A.-Hermsen, J. M.-Ovadia, S. [2001]: The Glass Ceiling Effect. Social Forces, Vol. 80. No. 2. 655-681. o. https://doi.org/10.1353/sof.2001.0091.

Dries, N.-Pepermans, R.-Carlier, O. [2008]: Career success: Constructing a multidimensional model. Journal of Vocational Behavior, Vol. 73. No. 2. 254-267. o. https://doi. org/10.1016/j.jvb.2008.05.005.

Dusa ÁGnes RéKa [2015]: A nemzetközi hallgatói mobilitás értelmezése eredményességi szempontból. Megjelent: Pusztai Gabriella-Kovács Klára (szerk.) [2015] 25-41. o.

GatTIKeR, U. E.-LARwood, L. [1989]: Career success, mobility and extrinsic satisfaction of corporate managers. The Social Science Journal, Vol. 26. No. 1. 75-92. o. https://doi. org/10.1016/0362-3319(89)90039-6.

GerLI, F.-Bonesso, S.-PizzI, C. [2015]: Boundaryless career and career success: the impact of emotional and social competencies. Frontiers in Psychology, Vol. 6. Article 1304, 1-17. o. https://doi.org/10.3389/fpsyg.2015.01304.

GUNZ, H.-MAYRHOFER, W. [2011]: Re-conceptualizing career success: a contextual approach. ZAF, Vol. 43. No. 3. 251-260. o. https://doi.org/10.1007/s12651-010-0049-z.

Heslin, P. A. [2005a]: Conceptualizing and evaluating career success. Journal of Organizational Behavior, Vol. 26. No. 2. 113-136. o. https://doi.org/10.1002/job.270.

Heslin, P. A. [2005b]: Experiencing Career Success. Organizational Dynamics, Vol. 34. No. 4. 376-390. o. https://doi.org/10.1016/j.orgdyn.2005.08.005. 
Hobfoll, S. E.-Halbesleben, J.-Neveu, J.-P.-Westman, M. [2018]: Conservation of resources in the organizational context: The reality of resources and their consequences. Annual Review of Organizational Psychology and Organizational Behavior, Vol. 5. No. 1. 103-128. o. https://doi.org/10.1146/annurev-orgpsych-032117-104640.

HRubos Ildikó (szerk.) [2012]: Elefántcsonttoronyból világítótorony. Aula Kiadó, Budapest. JASKolka, G.-BeYer, J. M.-TriCe, H. M. [1985]: Measuring and predicting managerial success. Journal of Vocational Behavior, Vol. 26. No. 2. 189-205. o. https://doi.org/10.1016/00018791(85)90018-1.

Judge, T. A.-Kammeyer-Mueller, J. D. [2007]: Personality and career success. Megjelent: Gunz, H.-Peiperl, M. (szerk.): Handbook of Career Studies. Sage Publications, Thousand Oaks, CA, 59-78. o.

Judge, T. A.-Cable, D. M.-Boudreau, J. W.-Bretz, R. D. [1995]: An empirical investigation of the predictors of executive career success. Personnel Psychology, Vol. 48. 485-519. o.

KAZÁr KLÁRA-KüRTÖsı ZsóFIA [2017]: Sikeres hallgatók? A végzett hallgatók elhelyezkedése a DPR kutatás tükrében. Megjelent: Vilmányi Márton (szerk.): Menedzsment innovációk az üzleti és a nonbusiness szférákban. SZTE Gazdaságtudományi Kar, Szeged, 185-202. o.

Kiss LÁszló-Veroszta Zsuzsanna [2012]: Frissdiplomások, 2011. Diplomás Pályakövetési Rendszer. Intézményi adatfelvétel a 2008-ban, illetve 2010-ben végzettek körében. Módszertani összefoglaló. Educatio NKft., Budapest.

KIss Zsuzsanna [2014]: A szakterületek konvertálhatóság és helyettesíthetőség szerinti újracsoportosítása diplomások körében. Szakképzési Szemle, 30. évf. 4. sz. 18-33. o.

Kiss Zsuzsanna [2016]: A diszciplína szerepe a felsőfokú végzettséggel rendelkezők munkaerő-piaci sikerességében. Gradus, 3. évf. 1. sz. 185-190. o. http://gradus.kefo.hu/ archive/2016-1/2016_1_ART_017_Kiss.pdf.

Kiss Zsuzsanna-BARIzsné Hadházi Edit [2016]: Műszaki diplomások munkaerő-piaci sikeressége. International Journal of Engineering and Management Sciences, Vol. 1. No. 1. 1-8. o. https://doi.org/10.21791/ijems.2016.1.26.

Koncz Katalin [2013]: A sikeres szervezeti karrierfejlesztés feltételei. Munkaügyi Szemle, 57. évf. 4. sz. 32-41. o.

Korupp, S. E.-Ganzeboom, H. B. G.-VAn der Lippe, T. [2002]: Do Mothers Matter? A Comparison of Models of the Influence of Mothers' and Fathers' Educational and Occupational Status on Children's Educational Attainment. Quality \& Quantity, Vol. 36. 17-42. o. https:// doi.org/10.1023/A:1014393223522.

Kraimer, M. L.-Greco, L.-Seibert, S. E.-Sargent, L. D. [2019]: An Investigation of Academic Career Success: The New Tempo of Academic Life. Academy of Management Learning \& Education, Vol. 18. No. 2. 128-152. o. https://doi.org/10.5465/amle.2017.0391.

LAne, J. E.-Johnstone, D. B. (szerk.) [2012]: Universities and Cilleges as Economic Drivers: Measuring higher education's role in economic development. SUNY Press, Albany, N. Y.

Ng, T. W. H.-Eby, L. T.-Sorensen, K. L.-Feldman, D. C. [2005]: Predictors of objective and subjective career success: A meta-analysis. Personnel Psychology, Vol. 58. No. 2. 367-408. o. https://doi.org/10.1111/j.1744-6570.2005.00515.x.

Nicholson, N.-West, M. A. [1988]: Managerial job change. Men and women in transition. Cambridge University Press, Cambridge.

Nyüsti Szilvia-Veroszta Zsuzsanna [2015]: A felsőoktatási életútra ható intézményi tényezők. Megjelent: Pusztai Gabriella-Kovács Klára (szerk.) [2015] 118-132. o.

Poole, M. E.-LAngan-Fox, J.-Omodei, M. [1993]: Contrasting subjective and objective criteria as determinants of perceived career success: a longitudinal study. Journal 
of Occupational and Organizational Psychology, Vol. 66. No. 1. 39-54. o. https://doi. org/10.1111/j.2044-8325.1993.tb00515.x.

Powell, G. N.-Mainiero, L. A. [1992]: Cross-currents in the river of time: conceptualising the complexities of women's careers. Journal of Management, Vol. 18. No. 2. 215-237. o. https://doi.org/10.1177/014920639201800202.

Pusztai Gabriella-Kovács Klára (szerk.) [2015]: Ki eredményes a felsőoktatásban? Partium Press-Personal Problems Solution-Új Mandátum Könyvkiadó, Nagyvárad-Budapest.

Russo, N. F.-Kelly, R. M.-Deacon, M. [1991]: Gender and success-related attribution: beyond individualistic conceptions of achievement. Sex Roles, Vol. 25. No. 5-6. 331-350. o. https://doi.org/10.1007/bf00289760.

Seibert, S. E.-Crant, J. M.-Kraimer, M. [1999]: Proactive personality and career success. Journal of Applied Psychology, Vol. 84. No. 3. 416-427. o.

Seibert, S. E.-Kraimer, M. L.-Liden, R. C. [2001]: A Social Capital Theory of Career Success. Academy of Management Journal, Vol. 44. No. 2. 219-237. o. https://doi.org/10.5465/3069452.

Singh, R.-Ragins, B. R.-Tharenou, P. [2009]: Who gets a mentor? A longitudinal assessment of the rising star hypothesis. Journal of Vocational Behavior, Vol. 74. No. 1. 11-17. o. https://doi.org/10.1016/j.jvb.2008.09.009.

SIPOS NORBERT [2018]: Nemzetközi pályakövetési gyakorlatok és a magyar pályakövetési rendszer. A Diplomás Pályakövető Rendszernek az Állami Adminisztratív Adatbázisok Integrációjával való egyezőségének vizsgálata. Doktori értekezés, Pécsi Tudományegyetem, Pécs.

Spurk, D.-Hirschi, A.-Dries, N. [2019]: Antecedents and Outcomes of Objective Versus Subjective Career Success: Competing Perspectives and Future Directions. Journal of Management, Vol. 45. No. 1. 35-69. o. https://doi.org/10.1177/0149206318786563.

Sturges, J. [1999]: What it Means to Succeed: Personal Conceptions of Career Success Held by Male and Female Managers at Different Ages. British Journal of Management, Vol. 10. No. 3. 239-252. o. https://doi.org/10.1111/1467-8551.00130.

Szabó-BÁlint BrigitTA-Karoliny Mártonné [2019]: A karriersiker titka, avagy a siker elérését befolyásoló tényezők. Megjelent: László Gyula-Németh Julianna-Sipos Norbert (szerk): Vezető és menedzser. Emlékkötet Farkas Ferenc születésének 70. évfordulójára. Pécsi Tudományegyetem Közgazdaságtudományi Kar Vezetés- és Szervezéstudományi Intézet, Pécs, 166-173. o. http://pea.lib.pte.hu/handle/pea/23524.

VAn MaAnen, J. [1977]: Experiencing organization: Notes on the meaning of careers and socialization. Megjelent: Van Maanen, J. (szerk.): Organizational careers: Some new perspectives. Wiley, New York, 15-45. o.

VARGA JÚLIA [2013]: A pályakezdő diplomások munkaerő-piaci sikeressége 2011-ben. Megjelent: Frissdiplomások, 2011. Diplomás pályakövetés. Educatio Társadalmi Szolgáltató Közhasznú Társaság, Budapest, 143-171. o.

Veroszta Zsuzsanna [2011]: A munkaerő-piaci sikeresség dimenziói frissdiplomások körében. Megjelent: Garai Orsolya-Horváth Tamás-Kiss László-Szép Lilla-Veroszta Zsuzsanna (szerk): Frissdiplomások, 2010. Educatio, Budapest, 11-36. o.

Veroszta Zsuzsanna [2013a]: Diplomás pályakövetési adatok, 2013. Intézményi adatfelvételek. Educatio Nkft., Budapest.

Veroszta Zsuzsanna [2013b]: Frissdiplomások, 2012. Diplomás Pályakövetési Rendszer. Intézményi adatfelvétel a 2007-ben, 2009-ben, illetve 2011-ben végzettek körében. Módszertani összefoglaló. Educatio Nkft., Budapest.

Veroszta Zsuzsanna [2015a]: Adminisztratív adatok társadalomkutatási kezelése. Educatio, 24. évf. 3. sz. 3-14. o. 
Veroszta Zsuzsanna [2015b]: Diplomás Pályakövetési Rendszer országos kutatás. Kutatási zárótanulmány. Educatio NKft., Budapest.

Veroszta Zsuzsanna [2015c]: Frissdiplomások elégedettsége - az intézményi pályakövetési eredmények szerepe. Megjelent: Kuráth Gabriella-Héráné Tóth Andrea-Sipos Norbert (szerk.): PTE Diplomás Pályakövető Rendszer-tanulmánykötet 2015. Pécsi Tudományegyetem, Pécs, 97-116. o. https://marketing.pte.hu/sites/marketing.pte.hu/files/files/ Kutatasok/dpr_tankot_2015_fin_fh.pdf.

Vinogradov, Sz. [2017]: Measuring of the Labour-Market Success of Graduates of the Szent István University. Megjelent: Daróczi, M.-Robak, E.-Vinogradov, S. (szerk.): Management, organizations and society. Agroinform, Budapest, 41-52. o.

\section{Függelék}

\section{A szubjektív és objektív karriersikeresség pontértékei}

\section{Az objektív sikeresség tényezői}

OBJ1 - VEZETőI FELELőssÉG: alkalmazottak/beosztottak száma és vállalati méret - ami a szakmai státusra, a szervezeti hierarchiában elfoglalt helyre utal (lásd 2. táblázat); OBJ2 - TudÁs HASZNosíTÁsA: tanulmányok és a képzettség alkalmazása a munkában a szakmai előmenetelt és a tudás mértékét mutathatja: $\mathbf{1}$ - bármilyen szakterület, $\mathbf{2}$ - egy egészen más szakterület, 3 - a saját és kapcsolódó szakterület, 4 - csak a saját szakterület; овJ3 - Pozíció: szintén a szakmai státusra, illetve a presztízsre utal: 1 - beosztott, 2 alsóvezető, 3 - középvezető, 4 - felsővezető;

OBJ4 - MUNKÁBA ÁLLÁS IDEJE: milyen gyorsan sikerült munkát találnia a vizsgált személynek: 1 - több mint 12 hónap alatt helyezkedett el, 2 - 7-12 hónap alatt helyezkedett el, 3 4-6 hónap alatt helyezkedett el, 4 - az abszolutóriumkor vagy volt munkája, vagy legfeljebb 3 hónapon belül helyezkedett el;

OBJ5 - FIZETÉs: fizetés mértékének megállapítását szolgálta: 1 - a bruttó jövedelem alsó kvartilisébe esik, 2 - a bruttó jövedelem alsó középkvartilisébe esik, 3 - a bruttó jövedelem felső középkvartilisébe esik, 4 - a bruttó jövedelem felső kvartilisébe esik.

\section{A szubjektív sikeresség tényezői}

SZUBJ1 - A MUNKA SZEMÉLYI ÉS TÁRGYI KÖRÜLMÉNYEI (Összevontan a két kérdés átlagai): 1 - egyáltalán nem elégedett, 2 - inkább nem elégedett, 3 - inkább elégedett, 4 - teljes mértékben elégedett;

SZUBJ2 - A MUNKA SZAKMAI, TARTALMI RÉSZE: 1 - egyáltalán nem elégedett, 2 - inkább nem elégedett, 3 - inkább elégedett, 4 - teljes mértékben elégedett;

SZUBJ3 - SZAKMAI ELŐMENETEL, KARRIERÉPíTÉS: 1 - egyáltalán nem elégedett, 2 - inkább nem elégedett, 3 - inkább elégedett, 4 - teljes mértékben elégedett;

SZUBJ4 - Szakmai PRESZTízs: 1 - egyáltalán nem elégedett, 2 - inkább nem elégedett, 3 inkább elégedett, 4 - teljes mértékben elégedett;

SZUBJ5 - JöVEDELEM ÉS JUTTATÁsOK: 1 - egyáltalán nem elégedett, 2 - inkább nem elégedett, 3 - inkább elégedett, 4 - teljes mértékben elégedett. 